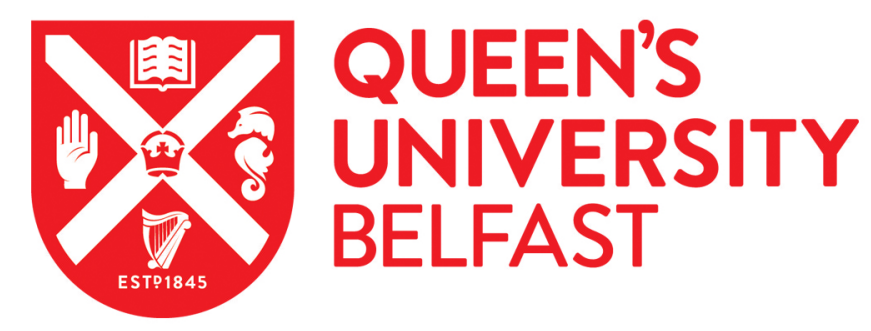

\title{
Influence of inoculation with Glomus mosseae or Acaulospora morrowiae on arsenic uptake and translocation by maize
}

Wang, Z. H., Zhang, J. L., Christie, P., \& Li, X. L. (2008). Influence of inoculation with Glomus mosseae or Acaulospora morrowiae on arsenic uptake and translocation by maize. Plant and Soil, 311(1-2), 235-244. https://doi.org/10.1007/s11104-008-9677-2

Published in:

Plant and Soil

Queen's University Belfast - Research Portal:

Link to publication record in Queen's University Belfast Research Portal

\section{General rights}

Copyright for the publications made accessible via the Queen's University Belfast Research Portal is retained by the author(s) and / or other copyright owners and it is a condition of accessing these publications that users recognise and abide by the legal requirements associated with these rights.

Take down policy

The Research Portal is Queen's institutional repository that provides access to Queen's research output. Every effort has been made to ensure that content in the Research Portal does not infringe any person's rights, or applicable UK laws. If you discover content in the Research Portal that you believe breaches copyright or violates any law, please contact openaccess@qub.ac.uk. 


\title{
Influence of inoculation with Glomus mosseae or Acaulospora morrowiae on arsenic uptake and translocation by maize
}

\author{
Zhen-Hui Wang • Jun-Ling Zhang • \\ Peter Christie $\cdot$ Xiao-Lin Li
}

Received: 18 March 2008 / Accepted: 2 June 2008 / Published online: 1 July 2008

(C) Springer Science + Business Media B.V. 2008

\begin{abstract}
A split root device was designed to assess the possible role of AMF in translocation and detoxification of As by maize plants. Half of each maize root system grew in As-amended or unamended soil and the remainder was inoculated with either Glomus mosseae or Acaulospora morrowiae. External mycelium was collected from a third compartment.
\end{abstract}

Responsible Editor: F. Andrew Smith.

Z.-H. Wang $\cdot$ J.-L. Zhang $(\bowtie) \cdot$ P. Christie $\cdot$ X.-L. Li

Key Laboratory of Plant Nutrition, Ministry of Agriculture,

China Agricultural University,

Beijing 100094, China

e-mail: junlingz@cau.edu.cn

Z.-H. Wang $\cdot$ J.-L. Zhang $\cdot$ P. Christie $\cdot$ X.-L. Li

Key Laboratory of Plant-Soil Interactions,

Ministry of Education, China Agricultural University,

Beijing 100094, China

Z.-H. Wang · J.-L. Zhang $\cdot$ P. Christie $\cdot$ X.-L. Li

College of Resources and Environmental Sciences,

China Agricultural University,

Beijing 100094, China

Z.-H. Wang

Rubber Research Institute/Ministry of Agriculture Key Laboratory for Tropical Crops, CATAS,

Danzhou, 571737 Hainan, China

P. Christie

Agricultural and Environmental Science Department,

Queen's University Belfast,

Belfast BT9 5PX, UK
Neither shoot nor root As concentrations were affected by inoculation with either fungus. Soil As amendment produced higher As concentrations in roots in the second compartment and in the external mycelium. The As concentrations in the matrix solution of the second root compartment were lower in mycorrhizal treatments with no differences in soluble As in the hyphal compartments. Mycorrhiza exerted little effect on As translocation within plants but may have influenced root As efflux. Deposition of As in external mycelium indicates a possible role of mycorrhizal fungi in the detoxification of As in the host plants.

Keywords Arbuscular mycorrhiza - Arsenic .

Phosphorus nutrition $\cdot$ Split-root device $\cdot$ Zea mays

\section{Introduction}

Arbuscular mycorrhizal (AM) fungi can form potentially beneficial associations with the roots of more than $80 \%$ of terrestrial plants and there is increasing evidence that AM fungi are important components of soil phytoremediation strategies for heavy metals (Khan et al. 2000) in terms of increasing plant growth and nutrient uptake (Smith and Read 1997) while enhancing metal uptake by plants or immobilization of metals in the soil. In some cases mycorrhizal plants show enhanced heavy metal(loid) uptake and root-toshoot transport (phytoextraction) in non-hyperaccu- 
mulators and in a few hyperacumulators such as Chinese brake fern for As (Al Agely et al. 2005; Leung et al. 2006) and Berkheya coddii for Ni. In other cases AM fungi contribute significantly to heavy metal immobilization in the soil (phytostabilization) beyond the rhizosphere and thereby enhance phytostabilization by releasing compounds or binding heavy metal(loids) to chitin in the fungal cell wall. By doing so, AM fungi reduce local metal concentrations in the soil or sequester the metals in underground parts of the symbiont, for example in root tissues and/ or fungal structures. The outcome of mycorrhizal colonization on clean-up of contaminated soils depends on the plant-fungus-heavy metal(loid) combination and is also influenced by soil conditions (Göhre and Paszkowski 2006).

Arsenic (As) is a ubiquitous toxic element and it has led to serious health problems, especially in some countries of south Asia (Abedin et al. 2002; Meharg 2004). Both As and $P$ are taken up via phosphate transporters on the plasma membrane of root epidermal cells (Ullrich-Eberius et al. 1989) because of their similar chemical behaviour (Meharg et al. 1994), and arsenate sensitivity is intimately linked to phosphate nutrition. In mycorrhizal plants 'mycorrhiza-induced' phosphate transporters (Rausch et al. 2001; Harrison et al. 2002) are exclusively expressed in mycorrhizal roots. The loss of function of the direct uptake pathway in roots colonized by AM fungi can apparently be complete in some AM associations (Smith et al. 2003). As direct uptake by roots declines, its replacement by the mycorrhizal pathway will depend on the expression of phosphate transporters in the external mycelium of the fungi (Harrison and van Buuren 1995; Maldonado-Mendoza et al. 2001). It is therefore assumed that mycorrhizal mycelium may perform a similar function in As uptake as in $\mathrm{P}$ uptake in As-contaminated soils. However, microorganisms can detoxify arsenate by reduction and efflux of arsenite (Ghosh et al. 1999; Shi et al. 1999; Mukhopadhyay et al. 2000; Mukhopadhyay and Rosen 2002; Rosen 2002), and plants have also been shown to have a high capacity to reduce arsenate (Meharg and Hartley-Whitaker 2002; Salt et al. 2002; Quaghebeur and Rengel 2003; Duan et al. 2005). Xu et al. (2007) recently reported that tomato and rice plants can release As via their roots. Although several studies have shown enhanced plant tolerance to As resulting from inoculation with AMF (Gonzalez-Chavez et al.
2002; Leung et al. 2006; Chen et al. 2007), elucidation of the effects of AMF on uptake and translocation of As and direct evidence showing that mycorrhizal hyphae are involved in the detoxification of As are still lacking. In the present study a split root device was used to assess the possible role of AMF in translocation and detoxification of As by maize plants. Arsenic taken up by a part of the root system growing in a mixture of soil and sand would be translocated to the shoots and into the part of the root system colonized by a mycorrhizal fungus or into external hyphae extending into a pot compartment containing glass beads so that external hyphae could be collected and analysed for As. Arsenic concentrations in the matrix solution were also determined. The study was designed to test the hypotheses that mycorrhizal colonization influences the translocation of As and that As efflux differs between mycorrhizal and non-mycorrhizal plant roots.

\section{Materials and methods}

\section{Experimental set up}

The split-root device shown in Fig. 1 was used. Two compartments, A $(10 \times 10 \times 4 \mathrm{~cm})$ and $\mathrm{B}(10 \times 10 \times$ $4 \mathrm{~cm}$ ) were used for the growth of two halves of the split root system of the maize plant. A mixture of soil and sand $(3: 1, v / v)$ was placed in compartment $\mathrm{A}$ and Perlite was placed in compartment B. The substrate in compartment A was amended with different levels of As and that in compartment B was either mixed with mycorrhizal inoculum or remained uninoculated. Compartment $\mathrm{C}(10 \times 10 \times 4 \mathrm{~cm})$, which was adjacent to compartment $\mathrm{B}$, was intended for hyphal growth. Glass beads $(<1 \mathrm{~mm})$ were used as the substrate so that extramatrical hyphae could be collected and analyzed as described in a previous study by Chen et al. (2001). The device was designed specifically to investigate the role of arbuscular mycorrhizal fungi in mediating As translocation and detoxification in the plants by determining As contents in different plant parts, and by measuring As in the external fungal mycelium and in the matrix solution. All materials used as substrates were sieved $(1.8 \mathrm{~mm})$ and sterilized by autoclaving at $120^{\circ} \mathrm{C}$ for $2 \mathrm{~h}$ prior to the experiment. Compartments $\mathrm{A}$ and $\mathrm{B}$ were separated by a polyvinylchloride $(\mathrm{PVC})$ plate $(10 \times 10 \times 0.2 \mathrm{~cm})$ 


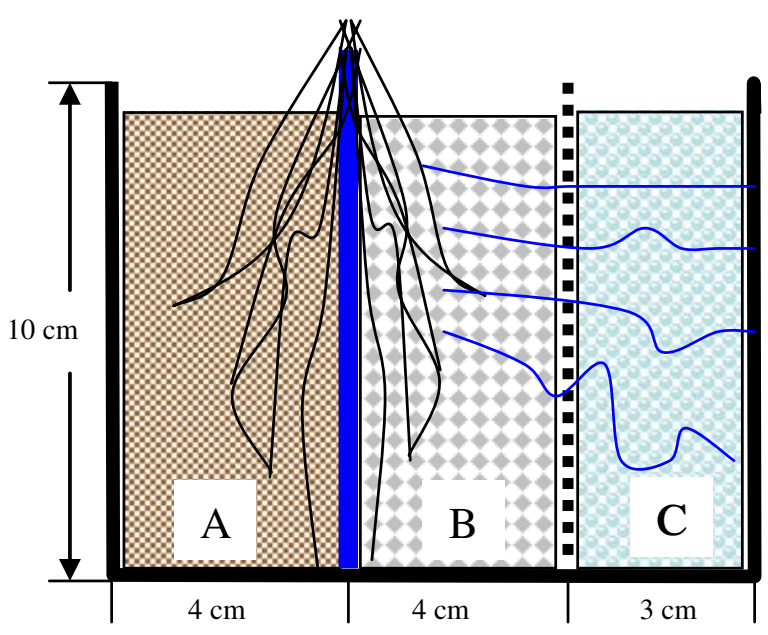

Fig. 1 Diagrammatic illustration of the split-root cultivation system. Compartments A and B were separated by a polyvinylchloride (PVC) plate and compartments $\mathrm{B}$ and $\mathrm{C}$ by a nylon screen $(30 \mu \mathrm{m}$ mesh). Roots of maize were split into compartments A and B. Arsenic was added to compartment A and mycorrhizal inoculum was added to compartment B. Compartment $\mathrm{C}$ was for hyphal growth. The substrate in compartment $\mathrm{A}$ was a mixture of soil and sand, and in compartments B and C were Perlite and glass beads, respectively. Hyphae are depicted as broken lines and maize roots as solid lines

and a nylon screen of $30 \mu \mathrm{m}$ mesh size was used to separate compartments B and C.

Biological material, growing conditions and experimental design

Two arbuscular mycorrhizal (AM) fungi, Glomus mosseae (Nicolson \& Gerdemann) Gerd. \& Trappe (BEG167; European Bank of the Glomales) and Acaulospora morrowiae Spain \& Schenck (BEG194) were used as inocula. The two fungi were propagated on the roots of maize plants in pot culture for 10 weeks. The inoculum consisted of growth medium containing spores together with infected maize root fragments. The experimental soil was collected from a field located at Danzhou city, Hainan province $\left(19^{\circ}\right.$ $30^{\prime} \mathrm{N}, 109^{\circ} 20^{\prime} \mathrm{E}$ ), south China. The soil had the following properties: $\mathrm{pH} 4.69$ (soil/water ratio, 1:2.5), organic matter content $0.46 \%, \mathrm{NaHCO}_{3}$-extractable $\mathrm{P}$ $0.21 \mathrm{mg} \mathrm{kg}^{-1}$, total As $1.40 \mathrm{mg} \mathrm{kg}^{-1}\left(\mathrm{HNO}_{3}-\mathrm{HClO}_{4}\right.$ digest; atomic fluorescence spectrometry). Other materials used were Perlite $(1-4 \mathrm{~mm})$, coarse river sand $(<2 \mathrm{~mm})$ and glass beads $(0.8-1.2 \mathrm{~mm}$ diameter). The glass beads and coarse river sand were acid- washed and all of the substrates were sterilised by autoclaving at $120^{\circ} \mathrm{C}$ for $2 \mathrm{~h}$ and then air-dried. Maize (Zea mays L. cv. Nongda 108) was used as the host plant.

The experiment consisted of a randomized block design with two factors: As level in which the substrate comprising a 3:1 ( v/v) mixture of soil and river sand in compartment $\mathrm{A}$ was amended with As at rates of 0,75 and $150 \mathrm{mg} \mathrm{kg}^{-1}$ in the form of $\mathrm{Na}_{3} \mathrm{AsO}_{4} \cdot 12 \mathrm{H}_{2} \mathrm{O}$ (roots were not inoculated), and the mycorrhizal treatment in which roots in compartment B were either non-mycorrhizal or inoculated with $G$. mosseae or A. morrowiae. Inoculum (50 g) was mixed with the Perlite in compartment B to produce inoculation treatments and $50 \mathrm{~g}$ sterilized inoculum plus $25 \mathrm{ml}$ mycorrhizal fungal-free filtrate from the inoculum suspension were added to produce the nonmycorrhizal treatments to provide a similar microflora except for the mycorrhizal fungus. There were nine treatments with four replicates, giving a total of 36 boxes. All treatments received mineral nutrients added to the soil as basal fertilizers at rates of $120 \mathrm{mg} \mathrm{kg}^{-1} \mathrm{~N}\left(\mathrm{NH}_{4} \mathrm{NO}_{3}\right), 20 \mathrm{mg} \mathrm{kg}{ }^{-1} \mathrm{P}\left(\mathrm{CaHPO}_{4}\right.$. $\left.2 \mathrm{H}_{2} \mathrm{O}\right)$ and $80 \mathrm{mg} \mathrm{kg}^{-1} \mathrm{~K}\left(\mathrm{~K}_{2} \mathrm{SO}_{4}\right)$. The substrate was incubated for 3 weeks after addition of the solution containing different As concentrations to allow equilibration of the added As.

Seeds of maize (Zea mays L.) were surface sterilized in a $10 \%(v / v)$ solution of hydrogen peroxide for $10 \mathrm{~min}$. They were pre-germinated for 2 days at $28^{\circ} \mathrm{C}$ and then sown in vermiculite. After growth for 10 days, seedlings with one taproot and eight to ten lateral roots were selected and transplanted in a split root chamber with one seedling per box. The lateral roots were separated into two equal parts and then placed in their two respective root compartments. The tap root was placed in compartment B to ensure good root growth and promote mycorrhizal colonization.

The experiment was conducted from August to October 2006 in a glasshouse at the Chinese Academy of Tropical Agricultural Science $\left(19^{\circ} 09^{\prime}\right.$ $\mathrm{N}, 108^{\circ} 51^{\prime} \mathrm{E}$ and $74 \mathrm{~m}$ above sea level), Hainan, south China. The temperature was $22-30^{\circ} \mathrm{C}$ without supplementary illumination. Water (or one fourth strength Hoagland's solution when necessary but with the $\mathrm{P}$ concentration reduced to one tenth) was added to the substrate in compartment A every 2 days. Twice each day $20 \mathrm{ml}$ one fourth strength Hoagland's 
solution with one tenth $\mathrm{P}$ was added to the Perlite in compartment $\mathrm{B}$, and the glass beads in compartment $\mathrm{C}$ were irrigated four times with $10 \mathrm{ml}$ one sixth strength Hoagland's solution with one tenth P. The water supply was controlled by measuring the water loss in unplanted control pots.

Harvest and chemical analysis

Plants were grown for 10 weeks and shoots and roots were harvested separately and rinsed twice with deionized water. Fresh portions $(1.0 \mathrm{~g})$ of the root samples were retained for determination of mycorrhizal colonization (Giovannetti and Mosse 1980). External mycelium was collected from compartment $\mathrm{C}$ of the inoculated treatments. Dry weights of shoots and the remaining roots and hyphae were determined after oven drying at $80^{\circ} \mathrm{C}$ for $48 \mathrm{~h}$. Shoots, roots and mycelium were milled and sieved (20 mesh) prior to chemical analysis. The samples were digested with concentrated $\mathrm{HNO}_{3}$ and deionized $\mathrm{H}_{2} \mathrm{O}(1: 1, v / v)$, followed by $30 \% \mathrm{H}_{2} \mathrm{O}_{2}$ for As determination (USEPA 1983 ) or with concentrated $\mathrm{HNO}_{3}, \mathrm{H}_{2} \mathrm{SO}_{4}$, and $30 \%$ $\mathrm{H}_{2} \mathrm{O}_{2}$ for P determination (Olsen and Sommers 1982). As concentration was determined using an atomic fluorescence spectrometer (Model AF-610A, Beijing Rayleigh Analytical Instruments, China), and $\mathrm{P}$ concentration was determined colorimetrically with a spectrophotometer using the standard vanadiummolybdenum yellow method (Murphy and Riley 1962). The proportions of As in shoots, roots grown in soil and Perlite were calculated as follows:

Shoot $-\mathrm{As} \%=($ As content in shoot $/$ plant total As content $) \times 100$

Soil root $-\mathrm{As} \%=($ Root As content $/$ plant total As content $) \times 100$

Perlite root $-\mathrm{As} \%=($ Shoot As content $/$ plant total As content $) \times 100$

The As content of the mycelium was not included in the calculation of total As content in mycorrhizal plants because the mycelium contained much less As than the other plant parts.

As concentrations in matrix solutions in compartments $\mathrm{B}$ and $\mathrm{C}$ were determined by using in situ buried anion exchange membrane (AEM) (Mallarino and Atia 2005). Sheets of a commercially available resin-impregnated plastic material (Chemical Plant, Shanghai, China) were cut into strips $(5 \times 2 \mathrm{~cm})$. The strips were soaked and washed in $95 \%$ ethanol for $1 \mathrm{~h}$, rinsed with deionized water, and then soaked in
$0.5 \mathrm{M} \mathrm{NaHCO}_{3}$ for $48 \mathrm{~h}$ and during this period the solution was replaced with fresh $\mathrm{NaHCO}_{3}$ at least four times. The strips were then maintained in deionized water prior to use. One strip was completely buried in the substrate about $2-3 \mathrm{~cm}$ below the surface of the substrates in the three compartments for $2 \mathrm{~h}$, maintaining the saturated status of the matrix solution. The strips were then removed, rinsed with deionized water, and shaken for $1 \mathrm{~h}$ in $20 \mathrm{ml} 0.5 \mathrm{M}$ $\mathrm{HCl}$ to desorb As. The As concentrations in the desorbent solutions were measured using the same method as described above.

The percentage of root length colonized by the mycorrhizal fungi was estimated randomly selected root segments. Root samples were cut into 1-cm-long bundles, cleared in $10 \%(w / v) \mathrm{KOH}$ at $90^{\circ} \mathrm{C}$ for $12-$ $15 \mathrm{~min}$ in a water bath, rinsed three times and then stained with Trypan blue at $90^{\circ} \mathrm{C}$ for $3-5 \mathrm{~min}$, stored in glycerine and measured by the gridline-intersect method (Giovannetti and Mosse 1980).

Statistical analysis

Data were analyzed using analysis of variance (ANOVA). Pairs of treatment means were compared using Duncan's multiple range test at the 5\% level. The SAS version 8.02 software package was used. Data are presented in the Tables as mean values $\pm \operatorname{SE}(n=4)$.

\section{Results}

Mycorrhizal colonization

No root colonization was observed in roots of nonmycorrhizal plants. Inoculated plant roots in compartment B had $48.2-72.2 \%$ and $59.3-79.5 \%$ of their length colonized by Glomus mosseae or Acaulospora morrowiae. The As addition level did not have significant effect on root colonization rates of either fungus but root colonization rates of both AM species at $75 \mathrm{mg} \mathrm{As} \mathrm{kg}{ }^{-1}$ tended to be higher than at zero As addition or $150 \mathrm{mg} \mathrm{As} \mathrm{kg}^{-1}$.

Dry weights of shoots and roots

Shoot dry weights were significantly affected by As addition levels but not by mycorrhizal colonization (Fig. 2, Table 1). Shoot dry weight at $150 \mathrm{mg} \mathrm{As} \mathrm{kg}{ }^{-1}$ 

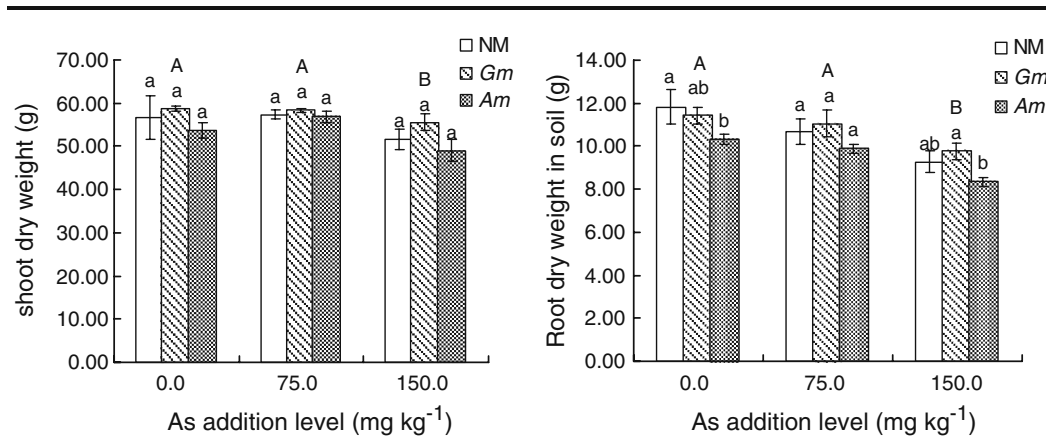

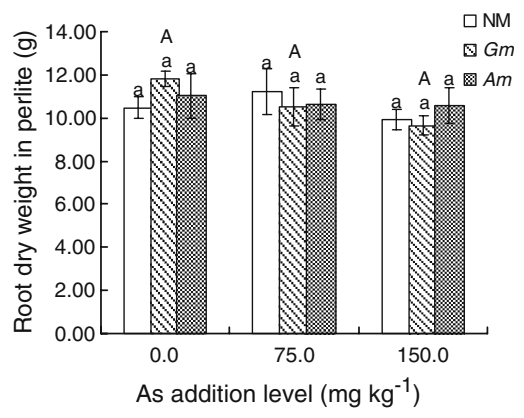

Fig. 2 Dry weights of Zea mays shoots and of roots (grown in soil and Perlite) inoculated with Glomus mosseae or Acaulospora morrowiae or uninoculated. Error bars: \pm SE. Lower case $a$ and $b$ indicate significant differences among control and the two mycorrhiza inoculation treatments at the same As addition levels. Upper case $A$ and $B$ indicate significant differences among the three means at different As addition levels

effect on dry weights of roots grown in Perlite (compartment $\mathrm{C}$ ).

$\mathrm{P}$ and As concentrations in shoots and roots

Plant $\mathrm{P}$ concentrations were about $0.63-0.97 \%$ on a dry matter basis and were presumably sufficient for adequate growth of the host plants under the experimental conditions because no symptoms of $\mathrm{P}$ deficiency were observed (Fig. 3). As additions to compartment A significantly increased P concentrations in roots grown in soil but had little effect on shoot $\mathrm{P}$ concentration or Perlite root $\mathrm{P}$ concentration (Table 1). Shoot $\mathrm{P}$ concentration in mycorrhizal plants was higher than in non-mycorrhizal controls amended with As. No significant difference was found between mycorrhizal and non-mycorrhizal plants in P concentrations of either half of the root systems regardless of As addition level.

Arsenic concentrations in shoots and roots of both non-mycorrhizal and mycorrhizal plants increased dramatically as As addition level increased (Fig. 4, Table 1). As concentrations in roots grown in soil were much higher than in roots grown in Perlite or shoot As concentrations. The highest As concentration observed approached $127.3 \mathrm{mg} \mathrm{kg}^{-1}$ in nonmycorrhizal roots grown in soil at $150 \mathrm{mg} \mathrm{As} \mathrm{kg}$ but the highest As concentration in roots grown in Perlite was only $2.3 \mathrm{mg} \mathrm{kg}$. Inoculation with a mycorrhizal fungus often had no significant effect on As concentrations of shoots or roots grown in soil

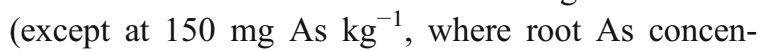
trations in mycorrhizal plants grown in soil were significantly lower than in the controls). 

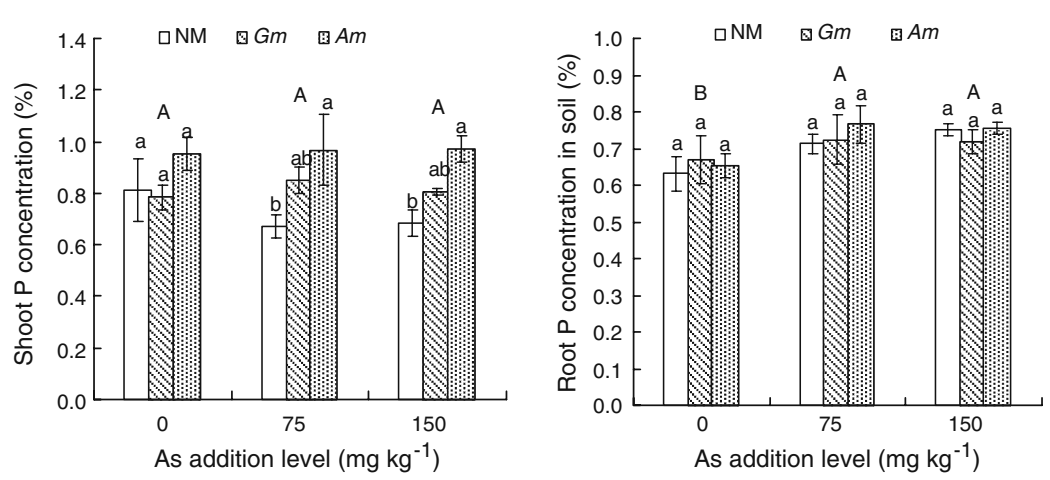

Fig. $3 \mathrm{P}$ concentrations of Zea mays shoots and roots (grown in soil and Perlite) inoculated with Glomus mosseae or Acaulospora morrowiae or uninoculated. Error bars: \pm SE. Lower case $a$ and $b$ indicate significant differences among

As concentrations in matrix solution

Soluble As concentrations in soil matrix solution were approximately 99-234 times higher than in Perlite (Fig. 5). As concentrations in soil matrix solution (compartment A) increased dramatically with increasing As addition level and at $150 \mathrm{mg}$ added $\mathrm{As} \mathrm{kg}^{-1}$ As concentrations in soil matrix solution significantly decreased in G. mosseae-inoculated treatments but increased in A. morrowiae-inoculated treatments. As concentrations in Perlite increased with increasing As addition level but the increase was more distinct in non-mycorrhizal plants than in mycorrhizal plants. Mycorrhizal colonization significantly decreased As concentrations in Perlite when As was added and there was no significant difference between the two fungi. As concentrations in the matrix solution of the control and the two mycorrhiza inoculation treatments at the same As addition levels. Upper case $A$ and $B$ indicate significant differences among the three means at different As addition levels

glass beads did not differ significantly among all treatments regardless of mycorrhizal inoculation or As addition level (Table 1).

As concentration in external mycelium

As concentrations in external mycelium of both fungi collected from the glass beads increased greatly with increasing As addition level. There was no significant difference between $G$. mosseae and A. morrowiae in the As concentrations in the external mycelium (Fig. 6).

Proportions of As in shoots and in roots grown in soil and Perlite

Neither mycorrhizal inoculation nor As addition level had any significant effect on the proportion of As in

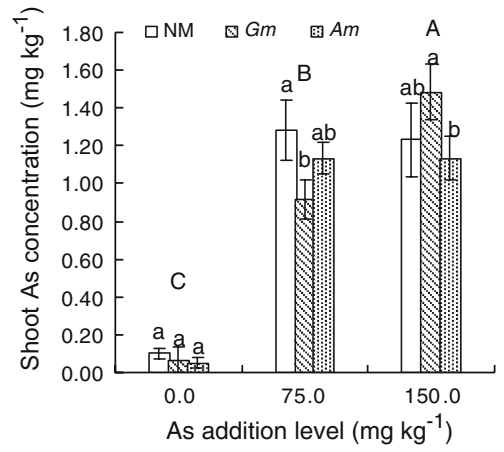

Fig. 4 Arsenic concentrations of Zea mays shoots and roots (grown in soil and Perlite) inoculated with Glomus mosseae or Acaulospora morrowiae or uninoculated. Error bars: $\pm \mathrm{SE}$. Lower case $a$ and $b$ indicate significant differences among
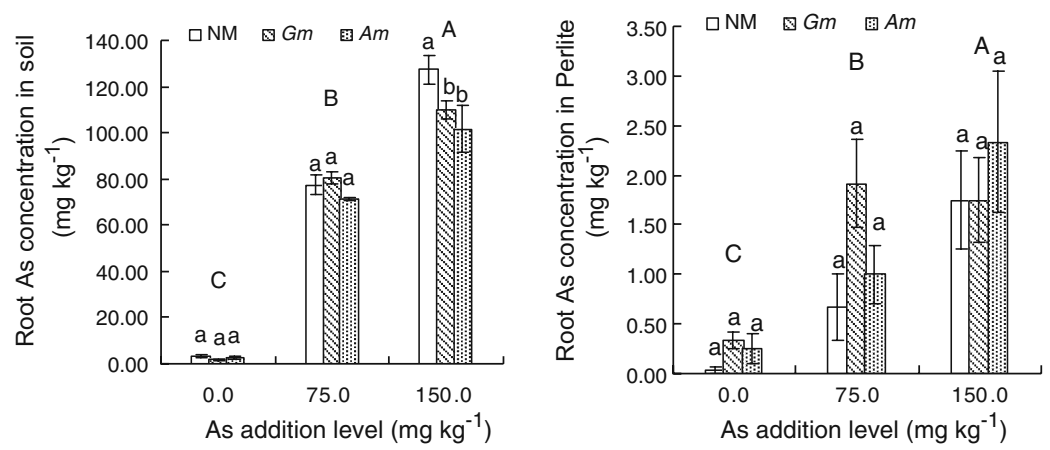

control and the two mycorrhiza inoculation treatments at the same As addition levels. Upper case $A, B$ and $C$ indicate significant differences among the three means at different As addition levels 

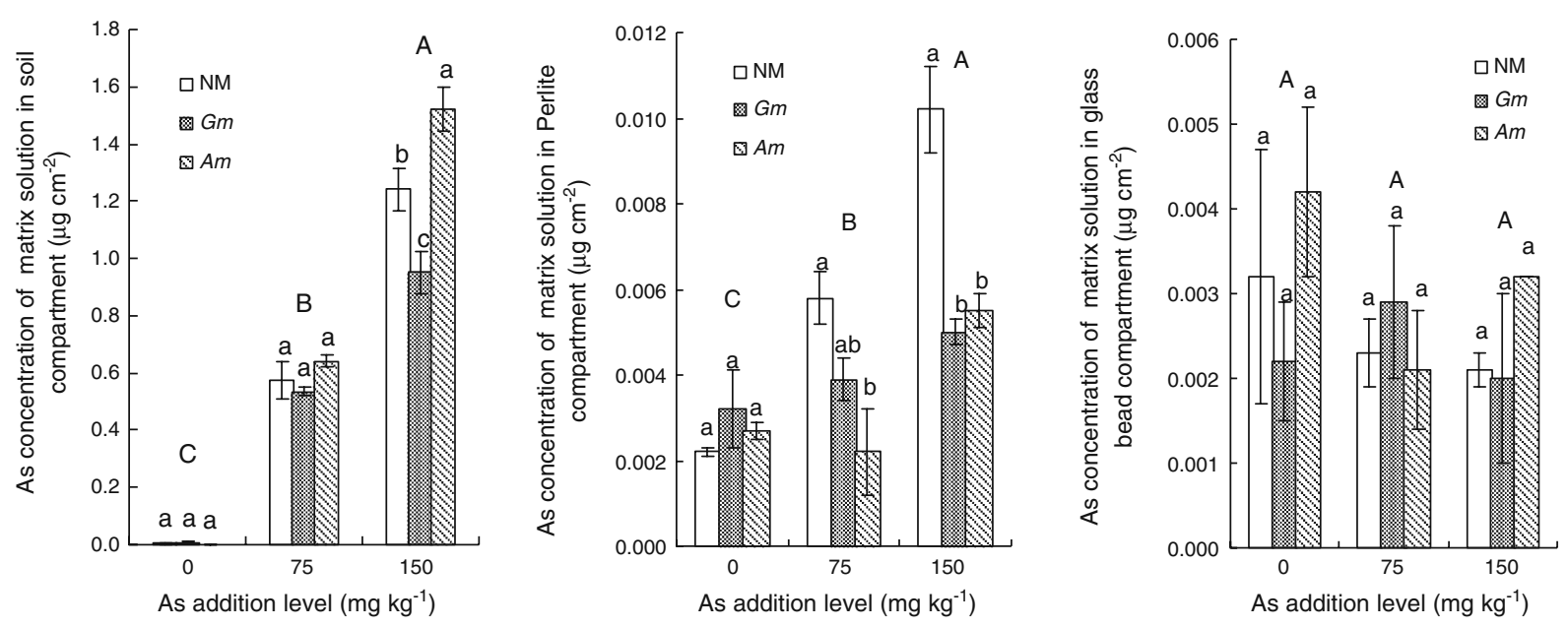

Fig. 5 Soluble As concentrations in the matrix solution in different compartments of the rhizoboxes. Error bars: \pm SE. Lower case $a, b$ and $c$ indicate significant differences among control and the two mycorrhiza inoculation treatments at the

shoots or roots of mycorrhizal plants grown in soil or Perlite (Table 2). Arsenic percentages in shoots were mostly between 6 and $7 \%$ and the values for roots grown in soil and Perlite were approximately 90 and $1.5-3.2 \%$ respectively.

\section{Discussion}

The split-root device used in the present study allowed us to investigate the long distance translocation of As within the plants and the possible role of mycorrhizal hyphae in mediating the process. Arsenic was mainly retained in the roots grown in the soil amended with As as shown by the higher concentration of As in the roots grown in soil compared to shoot As and roots grown in Perlite (Fig. 4). The proportions of As in shoots and in roots grown in soil and in Perlite were approximately 6-7, 90 and 1.5$3.2 \%$ when As was applied (Table 2), indicating that As was translocated from the roots grown in the As amended soil to the remainder of the plant parts. However, As translocation seemed to be limited by restricted upward transport of As from roots to shoots and retention of As in the roots, which has been suggested to be an effective mechanism for most nonhyperaccumulator plants to tolerate As (Ahmed et al. 2006; Leung et al. 2006; Meharg and Macnair 1991). In general, $\mathrm{As}(\mathrm{V})$ is taken up by the phosphate transporters in the plasma membrane while arsenite same As addition levels. Upper case $A, B$ and $C$ indicate significant differences among the three means at different As addition levels

is taken up via the aquaglycerolporin channel (Meharg and Hartley-Whitaker 2002). As(V) can be reduced to As(III) in the plant roots (Quaghebeur and Rengel 2003; Webb et al. 2003; Xu et al. 2007). On entering the roots, translocation of As within the plant occurs both symplastically and appoplastically, with a common pathway from roots to xylem, xylem to leaves, and leaves to phloem (Campos et al. 2004; Wachaupe 1983).

Inoculation with $G$. mosseae or A. morrowiae in the B compartment often had no significant effect on

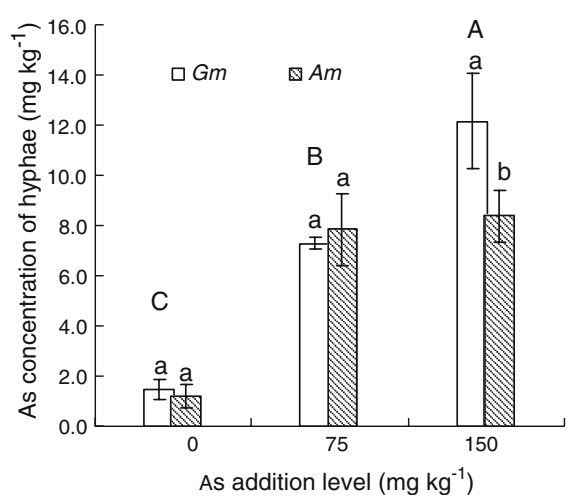

Fig. 6 Arsenic concentrations in hyphae collected from the glass bead compartment. Error bars: \pm SE. Lower case $a$ and $b$ indicate significant differences between plants inoculated with the two mycorrhizal fungi. Upper case $A, B$ and $C$ indicate significant differences among the three means at different As addition levels 
Table 2 Arsenic percentages in Zea mays shoots and roots (grown in soil and Perlite) inoculated with Glomus mosseae or Acaulospora morrowiae or uninoculated

\begin{tabular}{lllll}
\hline As addition level $\left(\mathrm{mg} \mathrm{kg}^{-1}\right)$ & Inoculation treatment & Shoot-As\% & Soil root-As\% & Perlite root-As\% \\
\hline 0 & G. mosseae & $7.25 \pm 3.85$ & $90.75 \pm 3.60$ & $2.00 \pm 0.84$ \\
75 & A. morrowiae & $5.98 \pm 2.64$ & $91.78 \pm 4.04$ & $2.24 \pm 1.65$ \\
& G. mosseae & $7.33 \pm 3.33$ & $91.15 \pm 2.47$ & $1.52 \pm 1.32$ \\
150 & A. morrowiae & $7.57 \pm 0.95$ & $90.59 \pm 1.09$ & $1.84 \pm 0.77$ \\
& G. mosseae & $9.43 \pm 1.47$ & $88.55 \pm 2.05$ & $2.02 \pm 0.94$ \\
\hline
\end{tabular}

Data are means $\pm \operatorname{SD}(n=4)$

shoot or root As concentrations (Fig. 4) and this was unexpected because an increase in shoot $\mathrm{P}$ concentration was observed in mycorrhizal plants (Fig. 3). If As (V) was the main form of As translocated within the plants an increase in shoot As concentration would be expected. We therefore assume that As is very likely translocated mainly in the form of As (III) although the species of As present in the xylem sap was not determined. Recently Xu et al. (2007) showed that As (III) was the dominant form in xylem sap of Lycopersicon esculentum and Oryza sativa. By comparing two mutants of Arabidopsis thaliana, namely pho1 (P deficient) and pho2 (P accumulator) with the wild type, the earlier study by Quaghebeur and Rengel (2003) also suggested that As(III) was the main As species translocated and As was likely to be translocated via a different pathway to $\mathrm{P}$. The proportions of $\mathrm{P}$ in shoots and in roots grown in soil and in Perlite were approximately within the ranges of $70-77 \%, 10-14 \%$ and $10-16 \%$, which was in marked contrast to the As distributions in different plant parts (Table 2). Although As and $\mathrm{P}$ are analogues and arsenate and $\mathrm{P}$ are taken up by the same phosphate transporters in plant roots, there is growing evidence to indicate that As and $\mathrm{P}$ in the plant follow different metabolic pathways. The process of translocation of As within plants and the involvement of $\mathrm{P}$ in the process require further study.

Microbes detoxify arsenate by reduction and efflux of arsenite (Ghosh et al. 1999; Shi et al. 1999; Mukhopadhyay et al. 2000, Mukhopadhyay and Rosen 2002; Rosen 2002). Plants also have a high capacity to reduce arsenate (Meharg and HartleyWhitaker 2002; Salt et al. 2002; Quaghebeur and Rengel 2003; Duan et al. 2005), and recently Xu et al. (2007) found that tomato and rice roots rapidly reduced arsenate to arsenite while some of the arsenate and arsenite were actively released to the medium when plants were grown in solution culture. Efflux of As from mycorrhizal and non-mycorrhizal roots was also found in the present study and As concentrations in the matrix solution of mycorrhizal plant roots were significantly lower than of nonmycorrhizal roots (Fig. 5). The process and mechanism by which mycorrhizal plant roots exude less As is unclear and remains to be investigated. The presence of As in external mycelium (Fig. 6) indicates that As was translocated to the hyphae and can be deposited in the external mycelium. In the literature, apart from the P-mediated effect on the improvement of As tolerance in mycorrhizal plants (Ahmed et al. 2006; Chen et al. 2007; Xu et al. 2008), exclusion of As out of the roots and sequestering of As by binding on hyphae and other fungal tissues in the roots have often been proposed (Trota et al. 2006; Ultra et al. $2007 \mathrm{a}$, b) but have not yet been unequivocally demonstrated except for the observation of As efflux from the roots of Calluna vulgaris infected with Hymenocyphus ericae (Sharples et al. 2000) and Glomus species have been found to have a strong binding capacity for $\mathrm{Zn}$ and $\mathrm{Cd}$ (Joner et al. 2000). Our study provides some insight into these aspects by showing that mycorrhizal fungi may alter the efflux of As and As may be deposited in the hyphae. Recent studies by Ultra et al. (2007a, b) also showed that different As species occurred in the rhizosphere of mycorrhizal plants compared with non-mycorrhizal controls.

The two arbuscular mycorrhizal fungi G. mosseae and $A$. morrowiae showed similar affinities to the roots of maize as indicated by the percentages of root length colonized. Aside from a few exceptions, this 
often led to similar effects of inoculation of these two fungi on plant growth (Fig. 2), enhanced shoot $\mathrm{P}$ nutrition (Fig. 3), decreased As efflux into the substrate (Fig. 5) and deposition of As in the external mycelium (Fig. 6). A broad range of fungal species, particularly those fungi which have adapted to Ascontaminated sites, should be included to further elucidate the involvement of AM fungi in As translocation within plants.

In conclusion, our results indicate that As can be translocated within mycorrhizal maize, possibly mainly in the form of As(III). Inoculation with arbuscular mycorrhizal fungi may alter the efflux of As from plant roots and the deposition of As in the external fungal mycelium, implying a possible role for arbuscular mycorrhizal hyphae in the detoxification of As in the host plants.

Acknowledgments This work was funded by the National Natural Science Foundation of China (Projects 30571105 and 30370818), the British Council (Project DelPHE 1.64) and the Scientific Research Foundation for Returned Overseas Chinese Scholars, State Education Ministry. We also thank two anonymous reviewers whose helpful suggestions have greatly improved the manuscript.

\section{References}

Abedin MJ, Feldmann J, Meharg AA (2002) Uptake kinetics of arsenic species in rice plants. Plant Physiol 128:1120-1128

Ahmed FRS, Killham K, Alexander I (2006) Influences of arbuscular mycorrhizal fungus Glomus mosseae on growth and nutrition of lentil irrigated with arsenic contaminated water. Plant Soil 258:33-41

Al Agely A, Sylvia DM, Ma LQ (2005) Mycorrhizae increase arsenic uptake by the hyperaccumulator Chinese brake fern (Pteris vittata L.). J Environ Qual 34:2181-2186

Campos V, Aparecida M, Pires F (2004) Phytoremoval of arsenic from soil. Commun Soil Sci Plant Anal 35:2137-2146

Chen BD, Christie P, Li XL (2001) A modified glass bead compartment cultivation system for studies on nutrient and trace metal uptake by arbuscular mycorrhiza. Chemosphere 42:185-192

Chen BD, Christie P, Zhu YG, Smith FA, Xie ZM, Smith SE (2007) The arbuscular mycorrhizal fungus Glomus mosseae gives contradictory effects on phosphorus and arsenic acquisition by Medicago sativa Linn. Sci Total Environ 379:226-236

Duan GL, Zhu YG, Tong YP, Cai C, Kneer R (2005) Characterization of arsenate reductase in the extract of root and fronds of Chinese brake fern, an arsenic hyperaccumulator. Plant Physiol 138:461-469

Ghosh M, Shen J, Rosen BP (1999) Pathways of As (III) detoxification in Saccharomyces cerevisiae. Proc Natl Acad Sci U S A 96:5001-5006
Giovannetti M, Mosse B (1980) An evaluation of techniques for measuring vesicular arbuscular mycorrhizal infection in roots. New Phytol 84:489-500

Göhre V, Paszkowski U (2006) Contribution of the arbuscular mycorrhizal symbiosis to heavy metal phytoremediation. Planta 223:1115-1122

Gonzalez-Chavez C, Harris PJ, Dodd J, Meharg AA (2002) Arbuscular mycorrhizal fungi confer enhanced arsenate resistance on Holcus lanatus. New Phytol 155:163-171

Harrison MJ, van Buuren ML (1995) A phosphate transporter from the mycorrhizal fungus Glomus versiforme. Nature 378:626-632

Harrison MJ, Dewbre GR, Liu J (2002) A phosphate transporter from Medicago trunculata involved in the acquisition of phosphate released by arbuscular mycorrhizal fungi. Plant Cell 14:1-17

Joner EJ, Briones R, Leyval C (2000) Metal binding capacity of arbuscular mycorrhizal mycelium. Plant Soil 226:227-234

Khan AG, Kuek C, Chaudhry TM, Khoo CS, Hayes WJ (2000) Role of plants, mycorrhizae and phytochelators in heavy metal contaminated land remediation. Chemosphere 41:197-207

Leung HM, Ye ZH, Wong MH (2006) Interactions of mycorrhizal fungi with Pteris vittata (As hyperaccumulator) in As-contaminated soils. Environ Pollut 139:1-8

Maldonado-Mendoza IE, Dewbre GR, Harrison MJ (2001) A phosphate transporter gene from the extraradical mycelilum of an arbuscular mycorrhizal fungus Glomus intraradices is regulated in response to phosphate in the environment. Mol Plant Microbe Interact 14:1140-1148

Mallarino AP, Atia AM (2005) Correlation of a resin membrane soil phosphorus test with corn yield and routine soil tests. Soil Sci Soc Am J 69:266-272

Meharg AA (2004) Arsenic in rice: understanding a new disaster for South-East Asia. Trends Plant Sci 9:415-417

Meharg AA, Macnair MR (1991) The mechanisms of arsenate tolerance in Deschampsia cespitosa (L.) Beauv and Agrostis capillaris L. New Phytol 119:291-297

Meharg AA, Hartley-Whitaker J (2002) Arsenic uptake and metabolism in arsenic resistant and nonresistant plant species. New Phytol 154:29-43

Meharg AA, Bailey J, Breadmore K, Nacnair MR (1994) Biomass allocation, phosphorus nutrition and vesiculararbuscular mycorrhizal infection in clones of Yorkshire fog, Holcus lanatus L (Poaceae) that differ in their phosphate uptake kinetics and tolerance to arsenate. Plant Soil 160:11-20

Mukhopadhyay R, Rosen BP (2002) Arsenate reductase in prokaryotes and eukaryotes. Environ Health Perspect 110:745-748

Mukhopadhyay R, Shi J, Rosen BP (2000) Purification and characterization of Acr2p, the Saccharomyces cerevisiae arsenate reductase. J Biol Chem 275:21149-21157

Murphy J, Riley JP (1962) A modified single solution method for the determination of phosphate in natural waters. Anal Chim Acta 27:31-36

Olsen SR, Sommers LE (1982) Phosphorus. In: Page AL, Miller RH, Keeney DR (eds) Methods of soil analysis, Part 2. Chemical and microbiological properties. American Society of Agronomy and Soil Science Society of America, Madison, WI, pp 403-430 
Quaghebeur M, Rengel Z (2003) The distribution of arsenate and arsenite in shoots and roots of Holcus lanatus is influenced by arsenic tolerance and arsenate and phosphate supply. Plant Physiol 132:1600-1609

Rausch C, Darram P, Brunner S, Jansa J, Laloi M, Leggewie G et al (2001) A phosphate transporter expressed in arbuscule-containing cells in potato. Nature 414:462-470

Rosen BP (2002) Biochemistry of arsenic detoxification. FEBS Lett 529:86-92

Salt DE, Prince RC, Pickering IJ (2002) Chemical speciation of accumulated metals in plants: evidence from X-ray absorption spectroscopy. Microchem J 71:255-259

Sharples JM, Meharg AA, Chambers SM, Cairney JWG (2000) Mechanism of arsenate resistance in the ericoid mycorrhizal fungus Hymenoscyphus ericae. Plant Physiol 124:1327-1334

Shi J, Vlamis-Gardikas A, Aslund F, Holmgren A, Rosen BP (1999) Reactivity of glutaredoxins 1, 2, and 3 from Escherichia coli shows that glutaredoxin 2 is the primary hydrogen donor to arsC-catalyzed arsenate reduction. $\mathrm{J}$ Biol Chem 274:36039-36042

Smith SE, Read DJ (1997) Mycorrhizal symbiosis. Academic, London

Smith SE, Smith AF, Jakobsen I (2003) Mycorrhizal fungi can dominate phosphate supply to plants irrespective of growth responses. Plant Physiol 133:16-20

Trota A, Falaschi P, Cornara L, Minganti V, Fusconi A, Drava $\mathrm{G}$ et al (2006) Arbuscular mycorrhizae increase the arsenic translocation factor in the As hyperaccumulating fern Pteris vittata $\mathrm{L}$. Chemosphere 65:74-81

Ullrich-Eberius CI, Sanz A, Novacky AJ (1989) Evaluation of arsenate and vandate-associated changes of electrical membrane potential and phosphate transport in Lemna gibba GI. J Exp Bot 40:119-128

Ultra V, Tanaka S, Sakurai K, Iwasaki K (2007a) Effects of arbuscular mycorrhiza and phosphorus application on arsenic toxicity in sunflower (Helianthus annuus L.) and on the transformation of arsenic in the rhizosphere. Plant Soil 290:29-41

Ultra V, Tanaka S, Sakurai K, Iwasaki K (2007b) Arbuscular mycorrhiza fungus (Glomus aggregatum) influences biotransformation of arsenic in the rhizosphere of sunflower (Helianthus annuus L.). Soil Sci Plant Nutr 53:499-508

USEPA (1983) Method 3050. Acid digestion of sludges. Test methods for evaluating solid waste-Physical/chemical methods. SW846. USEPA, Washington, DC

Wachaupe RD (1983) Uptake, translocation and phytotoxicity of arsenic in plants. In: Fensterheim L (ed) Arsenic: industrial, biomédica, environmental perspectives. Arsenic Symposium, Gaithersburg, MD. Van Nostrand Reinhold Company, New York, pp 348-374

Webb SM, Gaillard JF, Ma LQ, Tu C (2003) (XAS) speciation of arsenic in a hyper-accumulating fern. Environ Sci Technol 37:754-760

$\mathrm{Xu}$ XY, McGrath SP, Zhao FJ (2007) Rapid reduction of arsenate in the medium mediated by plant roots. New Phytol 176:590-599

Xu PL, Christie P, Liu Y, Zhang JL, Li XL (2008) The arbuscular mycorrhizal fungus Glomus mosseae can enhance arsenic tolerance in Medicago truncatula by increasing plant phosphorus status and restricting arsenate uptake. Environ Pollut doi:10.1016/j.envpol.2008.01.003 